Available online at http://www.anpad.org.br/bar

\title{
Work in Multidisciplinary Teams: a Study about Mobilization of Knowledge and Learning in an Organization of Complex Products
}

Melissa Lucchi *

E-mail address: mluchi@gmail.com Fundação Armando Álvares Penteado - FAAP

São José dos Campos, SP, Brazil.

Mônica de Fátima Bianco E-mail address: mfbianco@ig.com.br Universidade Federal do Espírito Santo - UFES Vitória, ES, Brazil.

Paulo Tadeu de Mello Lourenção

E-mail address: paulol@univap.br Universidade do Vale do Paraíba - UNIVAP

São José dos Campos, SP, Brazil.

* Corresponding author: Melissa Lucchi

Rua José Cobra, 321, apto. 92A, Parque Industrial, São José dos Campos, SP, 12237-000, Brazil.

Copyright (C) 2011 Brazilian Administration Review. All rights reserved, including rights for translation. Parts of this work may be quoted without prior knowledge on the condition that the source is identified. 


\begin{abstract}
This article, the result of a Master's thesis, has as the main objective to investigate how trainee-engineers from the Advanced Training Program for Engineers (ATPE), from a Brazilian organization called Challenge, working in multidisciplinary teams with the help of mentors, interact and mobilize their knowledge, resulting in learning. To accomplish this, a Theoretical Reference Model based on the studies of Nonaka and Takeuchi (1997); Crossan, Lane and White (1999); Choo (2000, 2001); Garvin (2002); Schwartz (2003); Zietsma, Winn, Branzei and Vertinsky (2002); Senge (2006) and Castañeda, Rios (2007) and Pérez-Acosta (2005) was built. The data of this qualitative study case was garnered by an open questionnaire, individual interviews and questionnaires with a closed scale, applied in October and November of 2008. The results show that ATPE is seen as a proper driver of the mobilization, interaction and exchange of knowledge between trainee-engineers and mentors, resulting in learning at individual and group levels. Mentors are professionals that stimulate attention, autonomy and promote integration in an environment that simulates the business one. These aspects were seen as facilitators of the interaction and learning in ATPE. At the end, 18 notions were related to learning in ATPE and appear portrayed in an Empirical Representation done by authors.
\end{abstract}

Key words: knowledge; learning; interaction; mobilization; teamwork. 


\section{Introduction}

Since the second half of the twentieth century, the world has been going through transformations in the cultural, economic, educational, political, social and technological fields, indicating a faster rhythm of life. Values, relationships, systems and products are quickly becoming obsolete and disposable, knowledge and technologies have become specialized and more complex, requiring individuals to be more adaptable, flexible, creative, innovative and come up with rapid solutions in a continuous and permanent manner. These characteristics of the so-called post-modern society have caused a restructuring in social life and in the systems and structures of work (Gorz, 2004; Harvey, 2007; Toffler, 1994).

Being related to contemporary society, Organizational Learning, 'Organizations that Learn' and Knowledge Management are areas that have mobilized the attention of researchers, managers and academics in the world and in Brazil, especially in the last four decades. This research studies the organization called Challenge for the purposes of this research, and the program likewise called the Advanced Training Program for Engineers (ATPE), which focuses on the acceleration of learning. A requirement of the actual company was anonymity, so these pseudonyms were developed.

Having over ten thousand employees worldwide and operations in over 50 countries, Challenge lies in the southeast of Brazil and works with the development and manufacture of durable and complex goods. Developed in the last 10 years, the ATPE aims to train engineers from diverse specializations to act as future employees of Challenge. Lasting a year and a half, the Program consists of three stages: two theoretical and one practical. In the third (practice), engineer trainees work in multidisciplinary teams to simulate the preliminary design of a company product, and are guided by mentors who are more experienced professionals.

This article has as the main objective to investigate how engineer-trainees from the Advanced Training Program for Engineers (ATPE), from the organization here called Challenge, working in multidisciplinary teams with the help of mentors, interact with each other and mobilize their knowledge, resulting in learning. To achieve this objective, this research uses qualitative methods and a case study strategy. Studying the literature of Organizational Learning, Organizations that Learn and Knowledge Management, the researchers uncovered a Theoretical Model of Reference whose analytical categories (concepts) were used as a framework. Instruments used for obtaining data were: an open questionnaire, semi-structured individual interviews and a closed questionnaire. After analyzing the data, an Empirical Representation of Knowledge and Learning in ATPE was built.

The relevance of intellectual work in multidisciplinary work-force teams is the discussion in the second topic. The third topic presents contemporary theoretical approaches to the thematic areas of interest, which resulted in the Theoretical Reference Model that guided this study. In the fourth topic, methodological issues are defined and the organization (Challenge) and the program investigated (ATPE) are presented. The interpretation and analysis of data are brought in the fifth topic. Final considerations conclude this paper in the last topic.

\section{Non-Material Work in Multidisciplinary Teams}

The intellectual worker, who acts in complex contexts, as is the case in this research, must be able to make rapid decisions in uncertain conditions and constantly renew their skills (Harvey, 2007; Toffler, 1994). Their performance is related to their capacities for expression, motivation, coordination, communication and cooperation (Gorz, 2004, 2005). Called by Choo (2000) as an 'information professional' and by Toffler (1994) as 'modular man', to seek professional growth, he could be present in multiple locations and connect with various individuals in a fragmentary manner. 
Situated in a society where knowledge is the primary capital and the only constant seems to be change, he is required to use knowledge to the organization's benefit.

Knowledge is understood here in a complete vision: a wide awareness of an attitude, perspective or intention, its developments and implications (Pimenta \& Anastasiou, 2002). It has a character that is heterogeneous and difficult to measure, covering individuals' various capacities (Gorz, 2005). In the process of knowing, there is learning; which means expanding the capacity to create the desired results from a vision of the whole, which is obtained by interaction between individuals (Senge, 2006); and understanding, that is to mentally assimilate knowledge. Thus, comprehension is learned together with other individuals (Pimenta \& Anastasiou, 2002).

For purposes of this study, the word 'team' will be used in the sense of a semi-autonomous group comprised of engineers. This team will also be understood, based on the classification of Salerno (1999), as an open group, in which composition and functions of members vary. This type of group is responsible for challenging established assumptions and organizational boundaries.

In the specialized literature, there are many names used to refer to teams. This investigation will adopt multidisciplinary team and task-force team, used by Challenge (verbal information). The multidisciplinary teams involve professionals educated in various specialties, who share information, knowledge and experiences, working together on an activity (Nonaka \& Takeuchi, 1997; Toffler, 1994). It is important to emphasize the difference between task and activity. The classical concept of task is defined as a standard method, model and blueprint to carry out a procedure or an operation. The activity is related to real work - done by people - attached to certain professions that require specific skills (Salerno, 1999).

Teams are common in Training Programs or Experiential Learning Programs (Garvin, 2002) because they facilitate the sharing of complementary skills and experiential, tacit knowledges. They can be: (a) natural, consisting of "a head and their direct subordinates, or a group of functional specialists who work together" and (b) pairs, with "individuals with the same approximate level" (Garvin, 2002, p. 138). The mixture of the two is most appropriate, since it results in an increased exchange of experiences and learning because of the sharing of ideas between individuals from different cultural backgrounds.

Real problems (urgent projects of high visibility) or simulated (special tailored for specific learning needs) can be used. In the latter, there is a combination of realism and low risk, where failure is acceptable; it is useful to help avoid future real-life disasters. Participants are given autonomy during the challenges and are thus not afraid to take risks, which results in accelerated learning (Garvin, 2002). It is important to emphasize that the term training was adopted by fit the nomenclature used in organizations.

A training program requires trained professionals to guide people who are new to the company. The Project Manager is the leader of a team responsible for a specific project of product development. In Challenge, this assignment falls to mentors (verbal information). Specialists master certain technologies employed in the production and manufacturing process or in work methods (Rozenfeld et al., 2006). In Challenge, they accompany a mentor's work, in order to help the trainees with technical issues (verbal information).

\section{Theoretical Approaches in Organizational Learning: the Organization that Learns' and Knowledge Management}

\section{The 'organization that learns' of Garvin and Senge}

Adaptable and flexible to new ways of thinking and interacting, the 'Organization that Learns' requires the 'autonomous man', which deals with complex informations, defends his own thinking and 
is able to think together, question and improve system assumptions (Senge, 2006). It is perceived as "organizations where people continually expand their capacity to create the results they really desire, where new and embracing patterns of thought are stimulate and ... people learn continually how to learn together” (Senge, 2006, p. 37).

To Garvin (2002, p. 12), “An organization that learns is an organization skilled in the creation, acquisition, interpretation, transfer and retention of knowledge, and also in the deliberate modification of its behavior to reflect new knowledge and insights”. Members of this organization have a clear vision about their learning goals, seek information and analyze them by different approaches, and are receptive to dissonant views. After being disseminated, the ideas must become part of the organizational memory so that they can be accessed by other individuals and ensure their retention over time.

The development of the Organization that Learns was systematized by Senge (2006) into five disciplines. (a) The individual domain goes beyond the expertise, skills and abilities and refers to the creative process that leads to new learning and continuous personal growth. The individual must take an open and discursive posture towards new ideas. (b) The mental models are the means by which individuals understand and act in the world. When shared, they facilitate the relationship and increase interdependence between people. Exchanging information, knowledge and experience, people become more able to find reasonable solutions and innovate. (c) For the occurrence of the shared vision, they interact, negotiate, argue and explain points of view for common understandings. (d) Learning in teams is considered by the author as the most important of the five disciplines. The ability to learn together requires member discourse, allowing the emergence of new ideas and perceptions arising from an alignment of purpose. The idea is that the teams act as multipliers of innovative actions by interacting and sharing ideas with others through dialogue. (e) Linking the disciplines is systemic thinking: a non-linear way of thinking that provides relationships between events that are distant in time and space.

\section{Tacit and explicit knowledges of Nonaka and Takeuchi}

Studying the creation of knowledge in the organization, Nonaka and Takeuchi (1997) show two main types. The tacit is highly personal, rooted in the actions, experiences, emotions, beliefs and values of the individual. It can be divided into two dimensions: technical (skills, know-how) and cognitive (schemas, mental models, beliefs and rooted perceptions). To be shared, it's necessary that individuals interact and communicate, changing, reinterpreting and creating new meanings, ideas and actions (Nonaka \& Takeuchi, 1997). The importance of these ideas was also enhanced by Garvin (2002) and Senge (2006), who emphasized their significance in the team learning process.

Explicit knowledge can be articulated in verbal language, formalized in manuals or preserved in devices. It comprises the organizational memory, is easily accessed and transmitted, and is selfmultiplying. The interaction between the two knowledges provides for the creation of organizational knowledge, as held by the processes: socialization (tacit in tacit); externalization (tacit in explicit), combination (explicit in explicit) and internalization (explicit in tacit) (Nonaka \& Takeuchi, 1997).

Socialization occurs when experiences stemming from several individuals are shared, resulting in the creation and 'movement' of various tacit knowledge. Externalization can emerge from these dialogues and collective reflections. Explicit, this knowledge is available to members of the organization through printed, audiovisual or electronic media. Combination involves interaction between explicit knowledges, resulting in systemic knowledge. Internalization is the understanding, acceptance and internalization, by individuals, of formalized knowledge. To occur, experiences recorded in official documents are shared and re-tried, perpetuating themselves. The interaction of such content is described as a Spiral of Knowledge (Nonaka \& Takeuchi, 1997). 


\section{The knowing organization of Choo}

Choo's idea of tacit knowledge is similar to that of Nonaka and Takeuchi (1997); personal knowledge used by members of the organization to give meaning to their world (Choo, 2000, 2001; Choo \& Johnston, 2004). It is learned during periods of experience and practice, in which the individual develops the capacity to make judgments based on his intuition, in order to implement the optimal execution of an activity (Choo, 2000).

Explicit knowledge, according to Choo (2000, 2001; Choo \& Johnston, 2004), also similar to the perspective of Nonaka and Takeuchi (1997), is expressed in words, numbers, formulas, and easily communicated and disseminated in the organization. It can be based on objects and rules, codified in routines and procedures (Choo, 2000). Cultural knowledge can be understood as a conviction: shared beliefs which are considered true by members of an organization regarding their reality (Choo, 2000, 2001; Choo \& Johnston, 2004).

This knowledge circulates in the model that Choo (2001) called The Knowing Organization, composed of three items. (a) The attribution of meaning begins with the interpretation that something is changing in the environment (Weick, 1995 as cited in Choo, 2001). This requires that individuals converse and negotiate interpretations in order to achieve shared meanings and common goals that could explain the observed reality and allow for choices and actions that are favorable to the organization (Choo, 2001; Choo \& Johnston, 2004). Dialogue, interaction and exchange of ideas were also thought important by Nonaka and Takeuchi (1997), Garvin (2002) and Senge (2006). The significance of the interpretation will be seen in Crossan, Lane and White's model (1999), explained soon hereafter. (b) According to Choo (2001), the creation of knowledge is explained by the following paradigms: conversion of tacit knowledge into explicit (Nonaka \& Takeuchi, 1997); construction of knowledge (Leonard-Barton, 1995) and connection of separate and distinct knowledge (Badaracco, 1991). For Leonard-Barton (1995 as cited in Choo, 2001; Choo \& Johnston, 2004), the organization builds knowledge when it identifies and applies activities that boost its capacities, such as solving problems in teams with people from different specialties and the development of prototypes and integration of processes and tools. (c) Decision-making originates from a situation that requires the choice of a course of action.

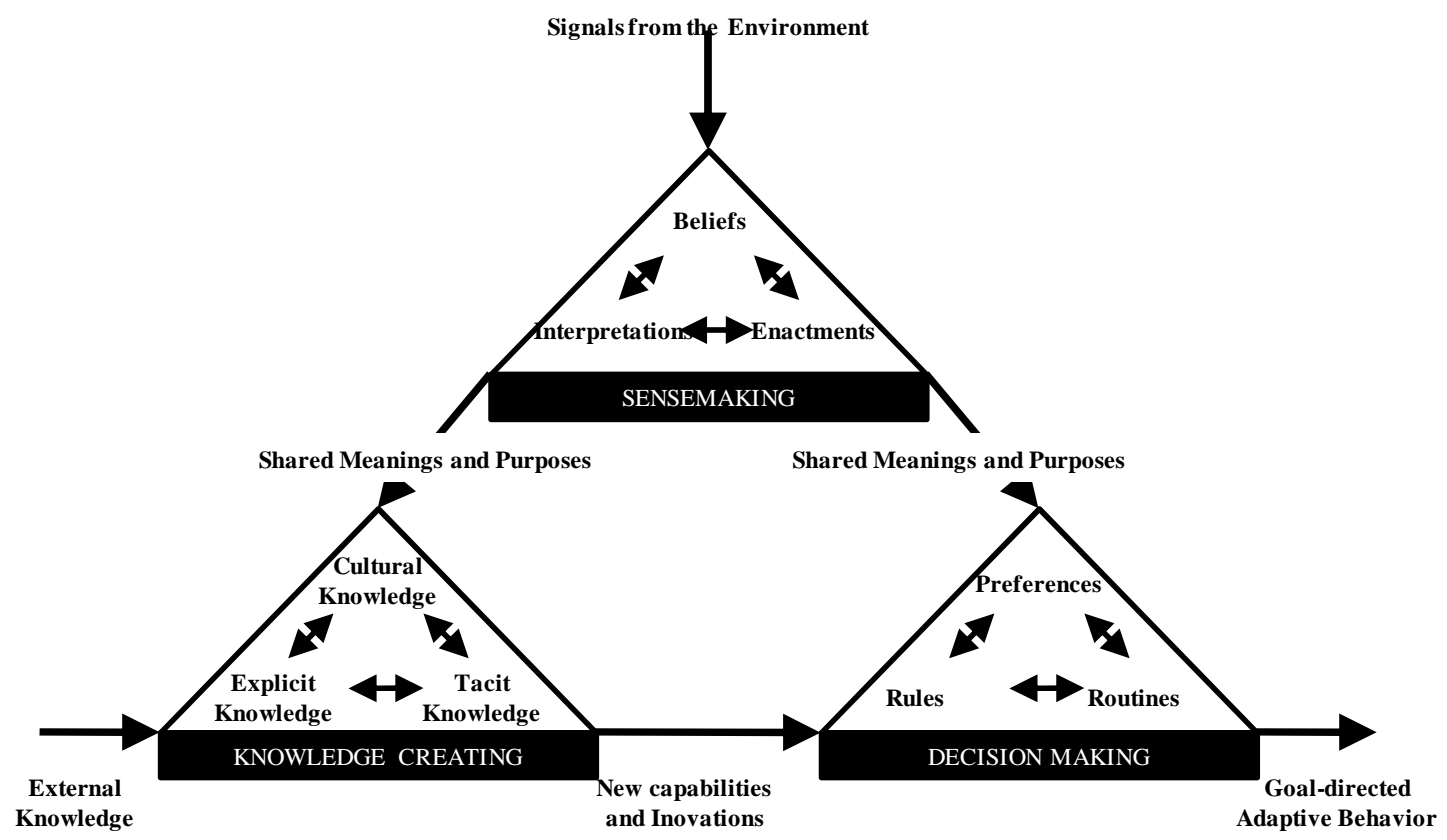

Figure 1. The Cycle of the Knowing Organization.

Source: Choo, C. W. (2001). The knowing organization as learning organization (p. 200). Education + Training, 43(4-5), 197-205. doi: 10.1108/EUM0000000005482 


\section{Work, knowledge and uses of self from Schwartz}

Perceiving work as an activity endowed with sense and history which can neither be generalized nor understood before it occurs, Veltz and Zarifian (1993), Schwartz (2003) and Gorz (2005) argue that knowledge production is the fruit of experience. It occurs by encountering something partially or totally unfamiliar with which individuals interact, learning and comprehending something. In the activities of work, knowledge is constructed and combined, being mobilized differently in every interaction. Because this individual and collective knowledge is under constant questioning and reconstruction, it results in new environments and issues needing to be resolved. They are influenced by production systems, technologies, organizational forms, procedures, interpersonal relationships and social relations. They are also accumulated in instruments, techniques, standards and organizational rules, which make up the formalized (Schwartz, 2003) or explicit knowledge (Nonaka \& Takeuchi, 1997).

This knowledge is related to the fact that the employee generates individual ways of doing things. The work activities become the dramatics of the use of self (Schwartz, 2003) or activities of producing of self (Gorz, 2005), in which the knowledge produced can't be described in the execution of a prescribed task, but rather by understanding the way in that men make history in their workplace (Schwartz, 2003). Depending on which knowledge is mobilized and recombined in their work, the individual and the team show which knowledge has great importance, endowing it with legitimacy. This analysis depends on life choices, values, cultures, experiences and previous decisions (Gorz, 2005; Schwartz, 1994, 2003).

\section{Intuition, interpretation, integration and institutionalization from Crossan, Lane and White}

The area of Organizational Learning is represented by the scholars Crossan et al. (1999) under four central assumptions: (a) it occurs at individual, group and organizational levels; (b) the three levels are linked to the processes of intuition, interpretation, integration and institutionalization; (c) it involves a tension between exploration and exploitation; (d) the action affects cognition and vice versa. It's relevant to add that the levels of the first assumption are assumed as central to learning to the authors cited before in this paper (Garvin, 2002; Nonaka \& Takeuchi, 1997; Senge; 2006). The processes of interpretation and integration can be results of the dialogue, interaction and communication between members of a team, as Garvin (2002) and Senge (2006) show. And institutionalization is similar to the explicit knowledge of Nonaka and Takeuchi (1997), when they prove that codified knowledge stays as organizational memory documents.

Largely unconscious, individual and differentiated according to the context and people involved, intuition is related to the insights, images and personal knowledge derived from experiences that, accumulated, build a mental map (Crossan, Lane, \& White, 1999). Regarding occurrences of situations involving cognition, interpretation 'enters into play' as a conscious process that can exist on an individual or team basis. It consists of the communication and explanation of insights to others (Crossan et al., 1999; Nonaka \& Takeuchi, 1997). The use of a common language leads to the integration of knowledge into mutual understandings between individuals who converse and share ideas, resulting in coordinated actions (Castañeda \& Pérez-Acosta, 2005; Castañeda \& Rios, 2007; Crossan et al., 1999; Nonaka \& Takeuchi, 1997; Senge, 2006; Zietsma, Winn, Branzei, \& Vertinsky, 2002).

When actions arising from integration become formalized rules and procedures, institutionalization occurs, that is, the learning contained in systems, structures, procedures and strategies is perpetuated in the organizational memory. If a procedure produces favorable results, is regulated by members and becomes routine (Crossan et al., 1999).

These processes are permeated by processes of exploitation of content already learned (exploitation or feedback) and assimilation of new learning (exploration or feed forward). In the 
former, what was learned returns from the organizational level (institutionalization) to group and individual levels (intuition), affecting the way people think and act. In the latter, new ideas and actions begin in the individual (intuition and interpretation), passing to the group and the organization (integration). Figure 2 shows the interaction between the 'stages'.

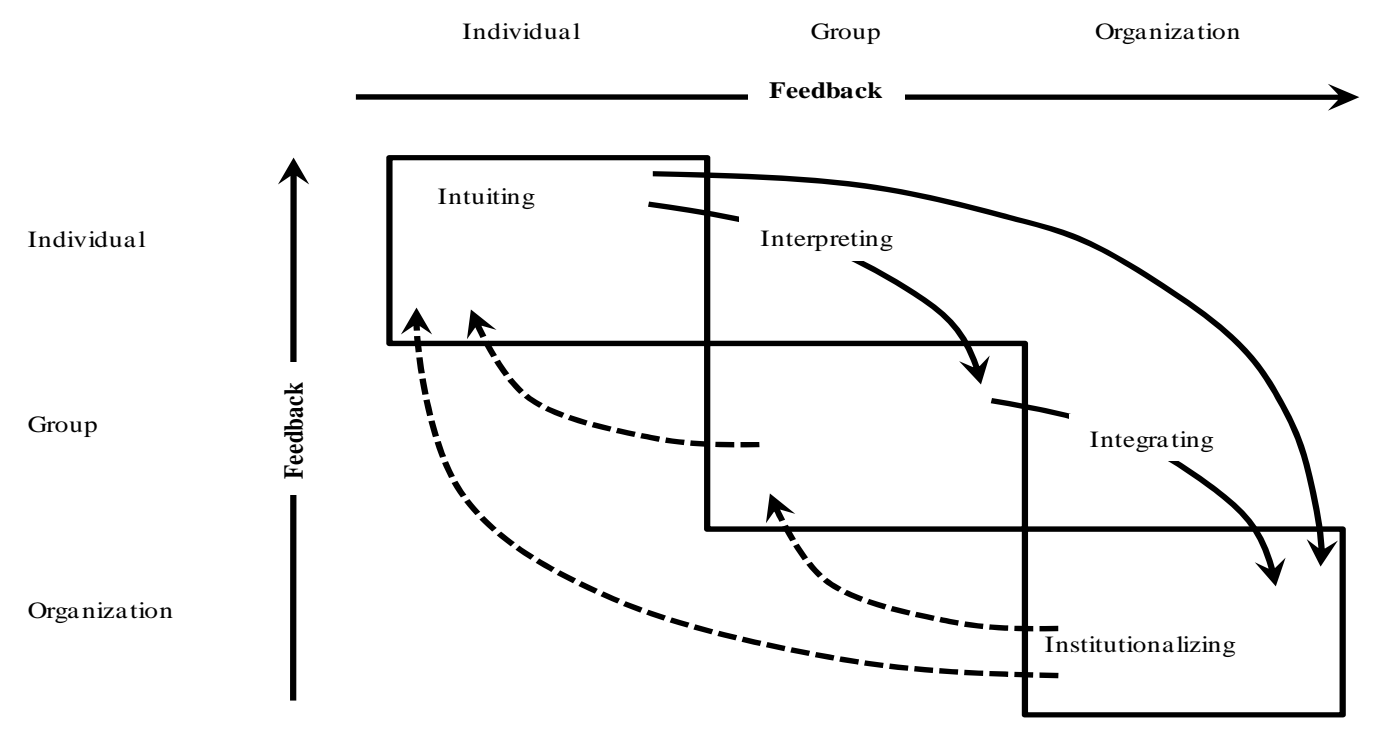

Figure 2. Organizational Learning as a Dynamic Process.

Source: Crossan, M. M., Lane, H. W., \& White, R. E. (1999). An organizational learning framework: from intuition to institution (p. 532). Academy of Management Review, 24(3), 522-537. doi: 10.2307/259140

\section{The contributions of Zietsma, Winn, Branzei, Vertinsky and Castañeda, Rios and Pérez- Acosta}

Crossan, et al. (1999), Zietsma, Winn, Branzei and Vertinsky (2002) add to the processes of intuition, interpretation, integration and institutionalization: (a) attention, which is the active search for and awareness of information in society; and (b) experimentation, where individuals and groups test possible behavior, resulting in joint actions and interpretations. These processes are summarized in Figure 3.

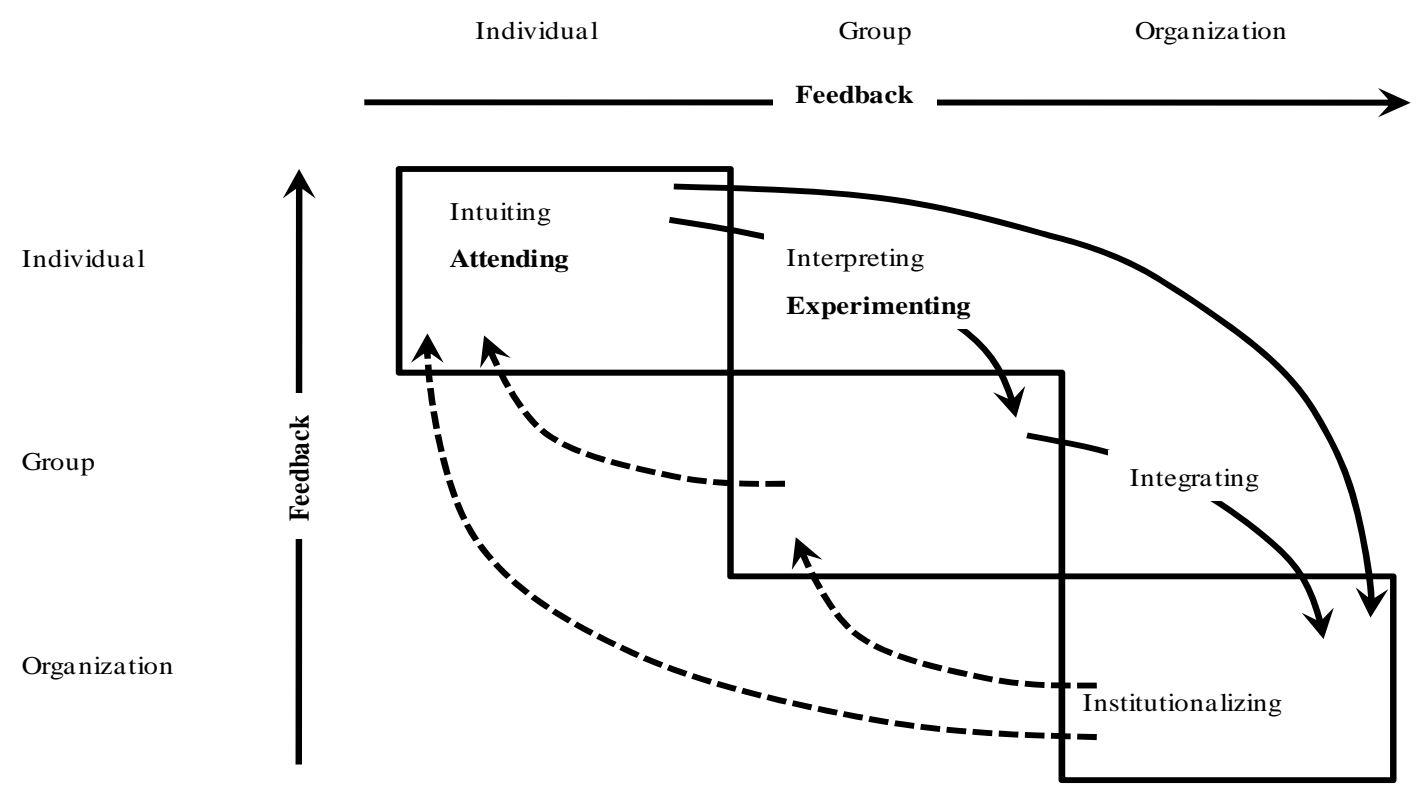

Figure 3. An Extended Framework for Feed-forward Learning Processes.

Source: Zietsma, C., Winn, M., Branzei, O., \& Vertinsky, I. (2002). The war of the woods: facilitators and impediments of organizational learning processes (p. S63). British Journal of Management, 13(S2), S61-S74. doi: 10.1111/1467-8551.13.s2.6 
Castañeda and Pérez-Acosta (2005) and Castañeda and Rios (2007) offer another complement to the model of Crossan et al. (1999). Based on the considerations of Zietsma et al. (2002), the authors add dialogue and socialization of behavior/actions. They emphasize the importance of dialogue in the interpretation because it is composed of thoughts and conscious observations. It also occurs with socialization, in a progression towards integration.

\section{Common points between the theoretical approaches: building a guiding model for this research}

From the understanding gained through the study of the theoretical approaches mentioned above, it was perceived that concepts of the areas Organizational Learning, Organizations that Learn and Knowledge Management are inter-related. Even using different names for some of them, scholars converge on many points, as shown in Table 1.

Table 1

Concepts from Authors of Organizational Learning, Organizations that Learn and Knowledge Management

\begin{tabular}{|c|c|}
\hline Concept & Author \\
\hline autonomy & Nonaka and Takeuchi (1997); Zietsma et al. (2002); Senge (2006) \\
\hline $\begin{array}{l}\text { dialogue, } \\
\text { interaction, } \\
\text { communication }\end{array}$ & $\begin{array}{l}\text { Nonaka and Takeuchi (1997); Crossan et al. (1999); Choo (2000, 2001) Choo and } \\
\text { Johnston (2004); Rullani (2000a, 2000b); Garvin (2002); Schwartz (2003); Senge (2006); } \\
\text { Castañeda and Pérez-Acosta (2005); Gorz (2005); Castañeda and Rios (2007) }\end{array}$ \\
\hline mental models & $\begin{array}{l}\text { Nonaka and Takeuchi (1997); Crossan et al. (1999); Choo (2000, 2001) Choo and } \\
\text { Johnston (2004); Zietsma et al. (2002); Garvin (2002); Senge (2006); Castañeda and Pérez- } \\
\text { Acosta (2005); Castañeda and Rios (2007) }\end{array}$ \\
\hline metaphor & $\begin{array}{l}\text { Nonaka and Takeuchi (1997); Crossan et al. (1999); Choo (2000, 2001) Choo and } \\
\text { Johnston (2004); Zietsma et al. (2002) }\end{array}$ \\
\hline shared vision & $\begin{array}{l}\text { Nonaka and Takeuchi (1997); Crossan et al. (1999); Choo (2000, 2001) Choo and } \\
\text { Johnston (2004); Zietsma et al. (2002); Garvin (2002); Senge (2006) }\end{array}$ \\
\hline $\begin{array}{l}\text { learning in } \\
\text { teams }\end{array}$ & $\begin{array}{l}\text { Nonaka and Takeuchi (1997); Crossan et al. (1999); Choo (2000, 2001) Choo and } \\
\text { Johnston (2004); Rullani (2000a, 2000b); Zietsma et al. (2002); Schwartz (2003); Gorz } \\
\text { (2005); Senge (2006) }\end{array}$ \\
\hline experience & $\begin{array}{l}\text { Nonaka and Takeuchi (1997); Crossan et al. (1999); Choo (2000, 2001) Choo and } \\
\text { Johnston (2004); Schwartz (2003) }\end{array}$ \\
\hline cooperation & $\begin{array}{l}\text { Nonaka and Takeuchi (1997); Choo (2000, 2001) Choo and Johnston (2004); Rullani } \\
\text { (2000a, 2000b); Gorz (2005); Senge (2006) }\end{array}$ \\
\hline trust & Nonaka and Takeuchi 1997; Senge, 2006 \\
\hline interpretation & $\begin{array}{l}\text { Nonaka \& Takeuchi (1997); Crossan et al. (1999); Choo (2000, 2001) Choo and } \\
\text { Johnston (2004); Zietsma et al. (2002); Garvin (2002); Castañeda and Pérez-Acosta } \\
\text { (2005); Gorz (2005); Castañeda and Rios (2007) }\end{array}$ \\
\hline intuition & $\begin{array}{l}\text { Nonaka and Takeuchi (1997); Crossan et al. (1999); Choo (2000, 2001) Choo and } \\
\text { Johnston (2004); Zietsma et al. (2002); Garvin (2002); Gorz (2005); Senge (2006) }\end{array}$ \\
\hline
\end{tabular}

Considering these convergences, 18 concepts related to knowledge and learning in the contemporary organization were brought together in a Theoretical Model of Reference (Figure 4), guiding this research. Using a circular shape, the model shows the elements involved in the circulation of tacit knowledge as interdependent, without a distinction of importance, since an assumed equal 
participation in the learning process is obtained at the individual (eight concepts) and group levels (ten concepts) from the interaction between them.

Figure 4. Theoretical Model of Reference for the Study of the Mobilization of Tacit Knowledge and Subsequent Learning.

\section{Research Methodology and the Challenge Case}

\section{Methodological aspects}

This work uses a qualitative method (Brannen, 2004; Kvale, 2006; Ryan \& Bernard, 2000), being an applied, descriptive and explanatory case study (Roesch, 1999, p. 262), because this study intends "to try out one theoretical model". In addiction, it is important to reflect that "every social inquiry necessarily requires a range of different methods" whereas the dichotomy between qualitative and quantitative research has been rejected and "that research is complex and diversified in practice" (Brannen, 2004, p. 313).

The case examined here is the organization called Challenge and the social group studied are two classes of engineer-trainees from the company's Advanced Training Program of Engineers (ATPE). ATPE interacts in multidisciplinary work-teams with the help of mentors, a situation that occurs during the third stage of the program. The Theoretical Model of Reference guided the formulation of the content of the questionnaires used and the interview guide. The confidentiality of information concerning the company and the anonymity of the participants were assured. 
Composed of 16 questions, the initial questionnaire (open) was sent by email to 114 engineertrainees from two classes of ATPE in October 2008. The goal was to raise a profile of the main target audience of the research, identifying characteristics such as: age; marital status; area of academic training; participation in business trainings; experience with teamwork; opinions on teamwork; and opinions about ATPE. In all, 33 engineer-trainees from the two classes responded to the instrument by email.

The second, and final, stage of the research took place in November 2008 and included the realization of semi-structured individual interviews with 24 of the 33 engineer-trainees who answered the initial questionnaire (marked by email and conducted after work in public places). In addition six mentors from a total of eight who answered the questionnaire were interviewed (performed in the company's facilities, using manual transcription), both accompanied by a questionnaire with 18 closed items.

In the script for the trainees' interview, 11 questions attempted to capture views about the ATPE, the teamwork in the third step of the Program; the interaction with colleagues and mentors; negotiation of new ideas; learning; facilitators and difficult aspects of learning in the ATPE. In interviews with mentors, 18 questions addressed: age; working time in the company and positions occupied; meaning of the experience as a mentor; relationship between mentoring, knowledge and learning; and facilitators and difficult aspects in the interaction and education of the trainees.

The answers to the initial questionnaire and the interviews were examined having as basis the analysis of textual content of the material obtained. This procedure creates quantitative indicators. "This kind of analysis - word counters - can help researchers to identify important constructs and can provide data for systematic comparisons across groups” (Ryan \& Bernard, 2000, p. 777).

The guiding criteria were: (a) presence of concepts from the Theoretical Reference Model in terms and expressions of similar spelling or even semantic meaning; and (b) presence of other words and expressions that characterize learning in ATPE. Soon after the interview, a closed questionnaire called Evaluation of the Research Parameters was delivered to trainees and mentors evaluating each of the 18 concepts of the Model regarding the process of learning in the multidisciplinary team of stage 3 of ATPE. The scale used had four levels (not important; slightly important; important and very important) similar to the Semantic Differential Scale, created by Osgood, Sucio and Tannenbaum (1957 as cited in Gil, 1999).

\section{Characterization of challenge and the proposal of ATPE}

Challenge is a global company that works with the development of complex products, whose business requires a large amount of capital, a qualified labor force, cutting-edge technology and longterm maturation of projects, all of which combine to signify high- risk ventures (Internal Document). It has a unit located in Southeast Brazil, which was the subject of this study. Challenge's products can be customized to meet the needs of customers with regard to comfort, performance and economy (Verbal Information). This characteristic emulates of Post-Fordism, because it refers to the production and delivery of differentiated services.

Challenge views its individual employees as the basis of the organizational development process. Understanding the role and importance of their attitudes, workers of all levels are responsible for interaction and integration activities with other areas (Internal Document). It is perceived that the direction given by Challenge to the concept activity is similar to the one from Salerno (1999), in which the worker acknowledges and participates actively in the work that he performs, interacting with others and contributing through their skills, abilities and particular uses of self (Salerno, 1999; Schwartz, 1994, 2003), towards the achievement of organizational objectives and improvement.

The ATPE began during the last decade. The initiative stemmed from the finding, according to the Company, that the market didn't supply engineers trained to develop complex products. Today, more than 600 engineers from different backgrounds have participated in the Program, whose 
educational guideline is to help incoming engineers specialize in areas of technical content, eventually enabling them to join the staff at Challenge after finishing the course. The acceleration of learning occurs through the process of learn by doing, mimicking stages of development and manufacturing of the products while working in multidisciplinary teams (Verbal Information).

The ATPE is divided into three stages, each with six months' duration and almost 500 cumulative class hours, which are held in the Company's. The first is Basic Training, where about 60 students receive a general notion about the company's area of and its products. In the second stage, Specific Training, engineers also attend class lectures, but focus on the engineering area in which they were educated, in order to adapt and tailor it to the Company's area of activity (Internal Document).

The Traineeship is the last stage, practical nature and called Simulation of Preliminary Design of a New Product. Students are divided into work teams and guided by two mentors (professionals with many years of experience in Challenge and holding a broad knowledge of products and processes). The assignment for the trainees is to prepare a business plan and develop the preliminary design of a hypothetical product; similar to the ones the Company markets (Internal Document).

\section{Interpretation and Results Analysis}

In all, 33 trainee-engineers of ATPE responded to the initial questionnaire. They were $87.8 \%$ men aged 24 to 30 years, mainly lived in the Southern (72.7\%) and South (15.6\%) of Brazil. Regarding their academic profiles, $87.7 \%$ studied at public universities, mostly in the states of São Paulo (43.7\%), Minas Gerais (43.7\%) and Espírito Santo (21.8\%). The movement of engineers from eight different Brazilian states to participate in the ATPE seems to demonstrate the 'modular man' paradigm of Toffler (1994).

Regarding the time since graduation, $60.6 \%$ of trainee-engineers of ATPE were recent graduates, having been out of school for between 1 year to 2 years and 10 months. This finding is in agreement with one of the selection criteria for the program, which gives preference to engineers with a university degree received within the last $21 / 2$ years (Internal Document). The most common engineering areas in ATPE are: Electric (39.3\%), Mechanical (15.6\%) and Control and Automation (12.5\%). Regarding professional experience, $65.6 \%$ have worked; $81.2 \%$ have experience with teamwork; but $84.4 \%$ never participated in training programs in the business world.

In the initial questionnaire, engineer-trainees were asked what do they think and asked them to point out five keywords about the subjects teamwork (TW) and ATPE. Based on the Theoretical Reference Model created, the answers were searched for: (a) words with similar meaning to those contained in the Model and (b) other related terms. The concept 'learning' appears as the most common by engineer-trainees, both in relation to teamwork (16 times) and the ATPE (24 times). Other concepts of the Model that were common to both themes were: knowledge, experience and integration. The concept 'teamwork' was mentioned in relation to ATPE, which seems to indicate a perception on the part of the engineer-trainees about the interrelationship between the two.

Among other concepts mentioned by the engineer-trainees in the initial questionnaire (different from those contained in the Theoretical Model of Reference), diversity of people was the most common both in TW (12 entries) and ATPE (13). Other concepts common to both themes were: dedication, friendship and growth. It was noticed that some concepts seem contrary to others: organization (in TW) versus disruption (in ATPE); motivation (in TW) versus frustration (in ATPE), which may indicate differences between expectations (in TW) and what was experienced in ATPE, according to the respondents' opinion.

In the individual interviews held with the engineer-trainees, the strong connection between ATPE and the acquisition of knowledge and learning was noticed. These were the most common (205 citations) and third most common (87 citations) concepts in terms of number of entries in the 
interviews. This view is in line with Challenge's policy, which considers the locus of work as a place of teaching-learning. Speeches also refer to the intellectual capital (Gorz, 2004, 2005), valued by the Organization when it invests in the development of its workers (Garvin, 2002; Kiedrowski, 2006). The citations below illustrate this idea.

"Considering the technical knowledge, ATPE's experience has been fantastic! The learning rhythm of ATPE is higher than any other organization that I have participated" (T2).

"When you enter the Program, you know nothing. In the end, you're learning, you have certain knowledge. I believe that it's worthwhile. In terms of learning about Challenge, was marvelous!” (T17).

Two types of knowledge are circulating in the Program, according the engineer-trainees: the technical and relational. The first assumes greater importance: in the statements given to the researcher; for the two main facilitators of the interaction and learning mentioned in ATPE (coexistence with classmates and contact with the Company's professionals); for the concepts teamwork (96 citations) and interaction (84 citations), both of the Theoretical Model of Reference; and for the concept friendship (22 citations). The relational knowledge is similar to tacit knowledge. Technical knowledge is similar to explicit knowledge from Nonaka and Takeuchi (1997), and is codified in organizational norms and procedures. The following citations support this idea.

"When developing a product, you have technical knowledge and the other part is the knowledge of the process that creates a complex product. In this part, learning in group is essencial. In the Organization, we'lll have to work with different people” (T7).

"I'm learning many new things. The majority is technical, but I can't forget to mention that social part: talk, exchange information, look for people to try to improve communication. These are necessary attitudes, maybe the most important aspect” (T3).

The fourth most common concept in the textual content of interviews with engineer-trainees (84 endorsements) was the concept interaction. Some of the characteristics of this concept that were mentioned were: relate to, negotiate meanings, participate and think together with other individuals, comprehend experiences, and mutual knowledges in order to achieve a common direction for action (Veltz \& Zarifian, 1993). The trainees reported that the positive interaction, mutual support and teamwork toward a common focus (16 entries) promote convergence of actions and result in a climate of healthy competition (10 citations).

Work teams in stage 3 of ATPE may be considered mixed (Garvin, 2002), since both individuals with approximate level of knowledge (trainees) and functional experts (mentors) are involved. There, each engineer-trainee has specific tasks. The leader of each team coordinates and mediates the dialogue between members and between trainees and mentors. It is up to him to elicit questions, suggestions and requests from the team for the mentors (Verbal Information).

The concepts of the Theoretical Reference Model mentioned by the trainees in the interviews are shown in Figure 5. Other concepts related to learning in the ATPE are presented in Figure 6. Both were counted according to when the actual word or terms with similar meaning occurred, with the most cited term being used as the concept label. 


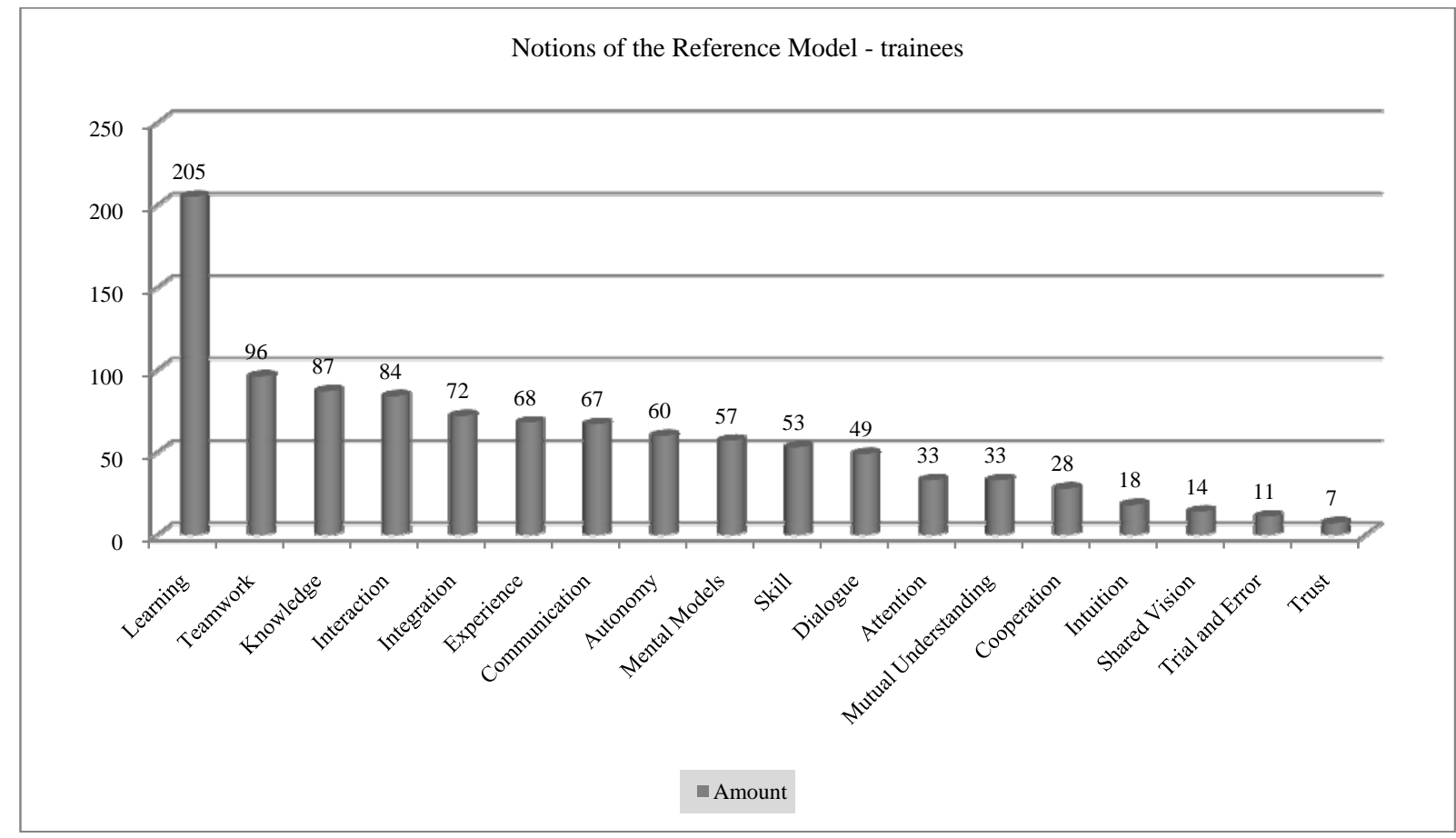

Figure 5. Concepts of the Theoretical Reference Model Frequently Mentioned by the Trainees in the Individual Interviews.

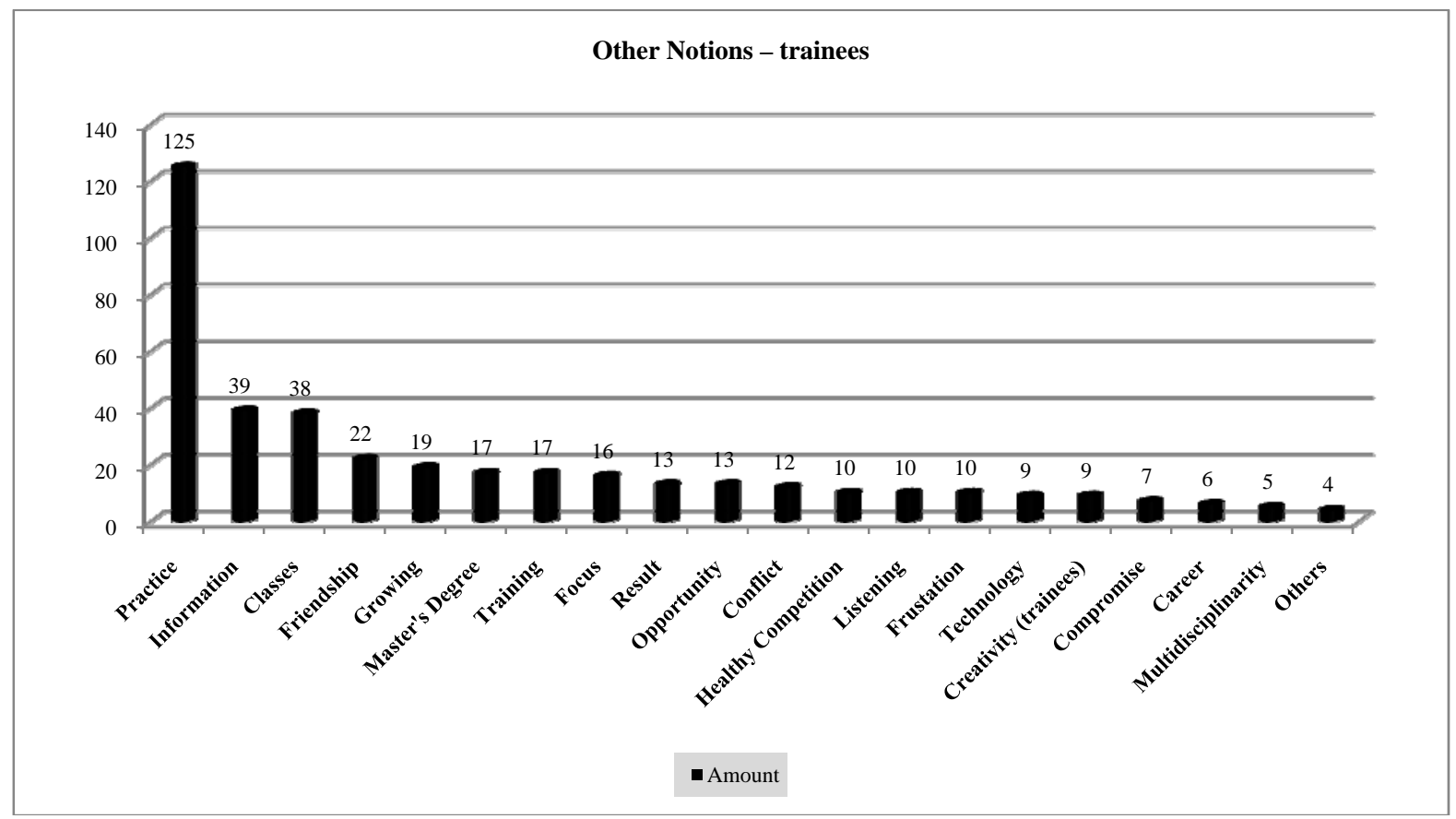

Figure 6. Other Concepts Frequently Mentioned by the Trainees in the Individual Interviews.

The trainee-engineers indicated 11 facilitating situations and attitudes regarding interaction and learning in ATPE, as seen in Table 3. The main facilitator is being together with people of the class, with their diverse viewpoints, characteristics and knowledge (mental models), which provided mutual assistance in activities of the program. To Rullani (2000a; 2000b), Davidz, Nightingale and Rhodes (2005), the joint action of individuals in different contexts multiply understanding, help empathy and strengthen the relationship. 
Table 3

Facilitators of the Interaction and Learning in ATPE

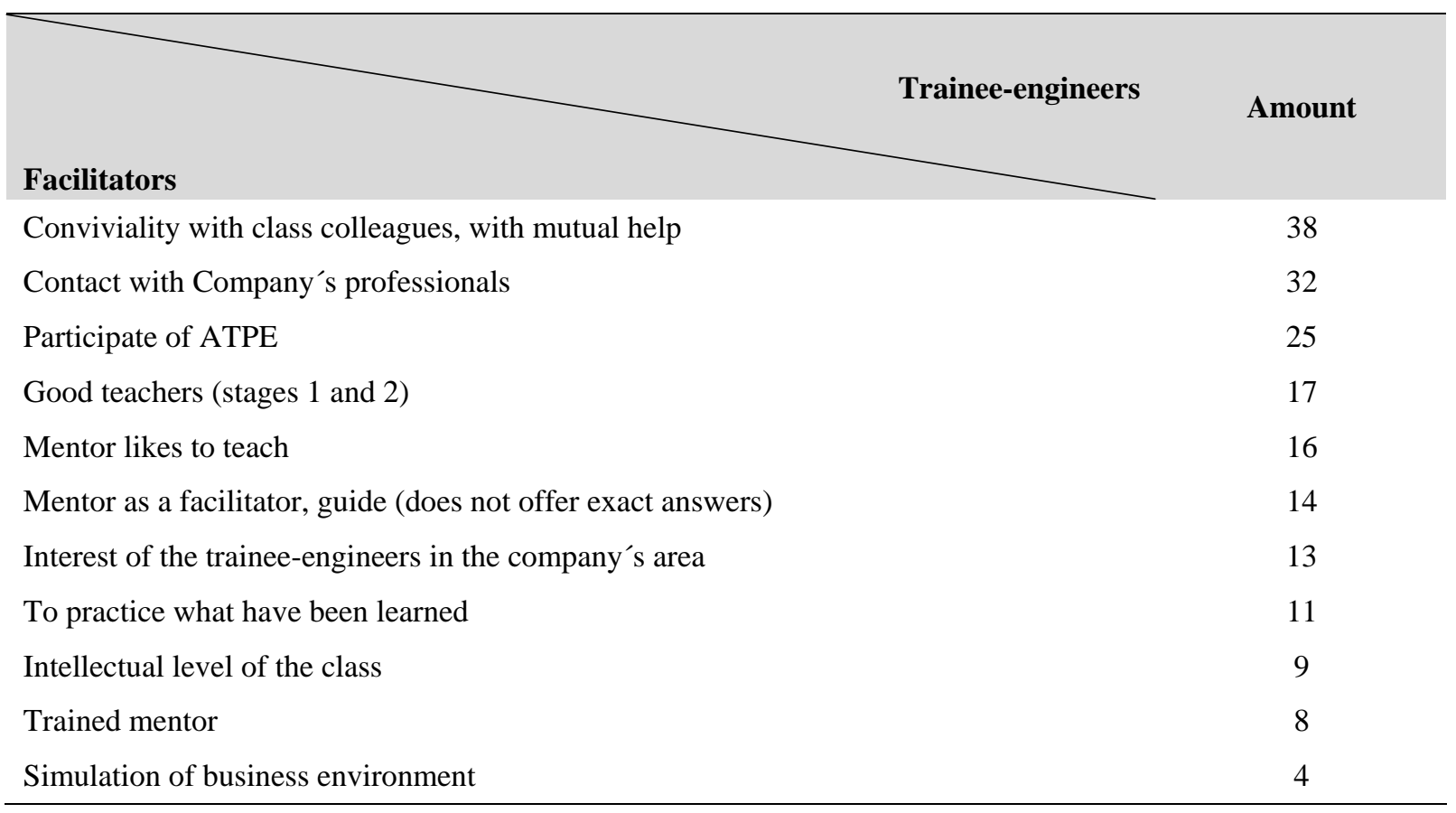

Contact with the company's professionals, made possible through mentors, is the second facilitator mentioned. The main advantages seen by engineer-trainees in this interaction is the exchange of information, experiences and the beginning of a network of contacts in the Company, a fact that may contribute to the progress of future works. For Toffler (1994) and Nonaka and Takeuchi (1997), the exchange of informations, knowledge, dialogue and joint activities result in learning for the members due to the exchange of experiences.

Six aspects remarking on the difficultly with the interaction and learning in ATPE stand out in the engineer-trainees' testimonies (Table 4). The main one consisted of operational difficulties on the part of those responsible for the Program. The problems included: (a) disciplines taught in an order that hindered the learning; (b) vacant time between the classes; (c) inadequacy of teachers' schedules; (d) lack of contact between the direction of ATPE and the trainees; (e) little time devoted to trainees' pursuit of the master's degree (four hours per month).

The limited availability of mentors' time appears as the third difficulty. Because mentoring isn't the main activity for some of Challenge's professionals, mentors share the work time between office affairs and mentoring. Thus, the engineer-trainees indicated that the mentor has only one day of the week dedicated to ATPE, an amount considered insufficient. 
Table 4

Difficult Aspects of Interaction and Learning in ATPE

\begin{tabular}{|c|c|}
\hline Trainee-engineers & Amount \\
\hline Operational difficulties from the ATPE's coordination & 20 \\
\hline ATPE having a high-school like atmosphere. & 16 \\
\hline Little availability of mentors' time & 12 \\
\hline Ego of some engineer-trainees & 8 \\
\hline Physical distance between units of the company & 6 \\
\hline Engineer-trainees’ restriction to access company information. & 4 \\
\hline
\end{tabular}

Examining terms and expressions cited by engineer-trainees in the initial questionnaires and in the interviews that refer to the interaction and learning in ATPE, it was noticed that some are repeated. Although not mentioned in the Theoretical Reference Model, they are congruent and relevant to the context studied, as shown in Table 5.

Table 5

Congruence between 'Other Concepts' According to the Trainees

\section{CONGRUENCE BETWEEN ‘OTHERS CONCEPTS’ ACCORDING TO TRAINEES}

\begin{tabular}{|c|c|c|c|}
\hline $\begin{array}{l}\text { In the initial } \\
\text { questionnaire }\end{array}$ & $\begin{array}{l}\text { In the content of the } \\
\text { interview }\end{array}$ & Among the facilitators & $\begin{array}{l}\text { Among the difficult } \\
\text { aspects }\end{array}$ \\
\hline $\begin{array}{l}\text { Exchange of information; } \\
\text { meet future co-workers }\end{array}$ & Information & $\begin{array}{l}\text { Contact with company's } \\
\text { professionals }\end{array}$ & $\begin{array}{l}\text { Restriction to access } \\
\text { information by the } \\
\text { engineer-trainees }\end{array}$ \\
\hline $\begin{array}{l}\text { Diversity (of people); sync/ } \\
\text { integration; aggregation/ } \\
\text { complementation; exchange } \\
\text { of ideas, relationships, } \\
\text { unity, friendship }\end{array}$ & Friendship & $\begin{array}{l}\text { Conviviality with people } \\
\text { of the class, with mutual } \\
\text { help }\end{array}$ & \\
\hline Frustration & Frustration & & Climate of college in ATPE \\
\hline Training & Training & Participate in ATPE & \\
\hline Classes & Classes & Good teachers & \\
\hline Disorganization & & & $\begin{array}{l}\text { Operational difficulties } \\
\text { from the ATPE's } \\
\text { coordination }\end{array}$ \\
\hline $\begin{array}{c}\text { Simulation of business } \\
\text { environment }\end{array}$ & & $\begin{array}{l}\text { Simulation of business } \\
\text { environment }\end{array}$ & \\
\hline Practice & & $\begin{array}{c}\text { Practice what has been } \\
\text { learned }\end{array}$ & \\
\hline
\end{tabular}


Two types of knowledge (technical and relational) concerning mentors emerged during the interviews, with the relational knowledge originating from the interaction between professionals and engineer-trainees. The statements also identify the mentor as a facilitator; a partner with more experience that guides, explains, helps, gives directions, but doesn't provide ready answers in order to stimulate attention, autonomy and challenge for the engineer-trainees. The main goals of mentoring cited were: (a) demonstrate the multidisciplinarity of the product and integration of the areas; (b) simulate the business that will be experienced by trainees; (c) group, in one place, people possessing different characteristics; (d) enhance communication, alignment of goals and ethics. According to Li and Gao (2003), a knowledge manager's task is to select the proper methodology and management techniques in order to cultivate and maintain a friendly, receptive climate for the socialization, externalization, combination and internalization of knowledge activities among individuals.

When mentors were asked to evaluate their experience in ATPE, the interviewees were unanimous in saying that the main benefit is the mutual learning (for trainees and mentors). Most stated the pleasure in using their knowledge and experiences to teach. In all, mentors pointed out 11 facilitating aspects for the interaction and education of the trainees (Table 6).

Table 6

Facilitators for Mentors' Interaction and Teaching in the ATPE

\begin{tabular}{|c|c|c|c|c|c|c|}
\hline \multirow[b]{2}{*}{ Facilitators } & \multirow[b]{2}{*}{ M1 } & \multirow[b]{2}{*}{ M2 } & \multirow[b]{2}{*}{ M3 } & \multirow[b]{2}{*}{ M4 } & \multirow[b]{2}{*}{ M5 } & \multirow[b]{2}{*}{ M6 } \\
\hline & & & & & & \\
\hline Ease of interaction / communication with the trainees & $\mathrm{X}$ & & $\mathrm{X}$ & $\mathrm{X}$ & $\mathrm{X}$ & $\mathrm{X}$ \\
\hline Share of knowledge and mutual learning & $\mathrm{X}$ & & $\mathrm{X}$ & $\mathrm{X}$ & $\mathrm{X}$ & $\mathrm{X}$ \\
\hline Interest of trainees in learning about the business of the Company & $\mathrm{X}$ & $\mathrm{X}$ & $\mathrm{X}$ & & & \\
\hline Like to teach & & & $\mathrm{X}$ & $\mathrm{X}$ & & \\
\hline Infrastructure of the Program (material and psychological) & & $\mathrm{X}$ & & & & $\mathrm{X}$ \\
\hline Teamwork & $\mathrm{X}$ & & & & & \\
\hline Proper process of selection of trainees by the Company & & & & & $\mathrm{X}$ & \\
\hline Creation, by ATPE, of expectations that result in tangible prospects & & $\mathrm{X}$ & & & & \\
\hline ATPE's focus on knowledge, not in evaluation & & & & $\mathrm{X}$ & & \\
\hline ATPE provides time for the exclusive dedication of the trainees to learning & & & & & & $\mathrm{X}$ \\
\hline Company's commitment to maintain the ATPE & & & $\mathrm{X}$ & & & \\
\hline
\end{tabular}

17 of the 18 concepts from the Theoretical Reference Model were present in the textual content of the interviews with mentors. The most significant in number were the terms learning (29 times) and knowledge (17), which demonstrates the close relationship between the concepts and mentoring. The concept from the Theoretical Reference Model most cited was integration (20 times), followed by communication (10), attention (8 times) and interaction (8 times). Other terms that characterize learning in teams in step 3 of ATPE are: experience/practice (20 times), expertise (13) and challenge (12). Six points were raised by mentors concerning difficult aspects for interaction and teaching in ATPE (Table 7). 
Table 7

Difficult Aspects for Interaction and Teaching in ATPE, According to Mentors

\begin{tabular}{|c|c|c|c|c|c|c|}
\hline \multirow[b]{2}{*}{ Difficult aspects } & \multirow[b]{2}{*}{ M1 } & \multirow[b]{2}{*}{ M2 } & \multirow[b]{2}{*}{ M3 } & \multirow[b]{2}{*}{ M4 } & \multirow[b]{2}{*}{ M5 } & \multirow[b]{2}{*}{ M6 } \\
\hline & & & & & & \\
\hline Difficult to balance working time and mentoring & $\mathrm{X}$ & $\mathrm{X}$ & $\mathrm{X}$ & & $\mathrm{X}$ & \\
\hline Perception, by trainees, of their self-sufficiency and self-confidence & & & $\mathrm{X}$ & $\mathrm{X}$ & & \\
\hline $\begin{array}{l}\text { Mistaken understanding of the importance of mentoring by company } \\
\text { professionals }\end{array}$ & $\mathrm{X}$ & & & & & \\
\hline Finding company professionals who would offer to help as specialists & & & & & $\mathrm{X}$ & \\
\hline $\begin{array}{l}\text { Physical distance between the units of the company in which they are } \\
\text { mentors and trainees }\end{array}$ & & & & & & $\mathrm{X}$ \\
\hline $\begin{array}{l}\text { Gap between steps } 1 \text { and 2, which is theoretical, and step 3, which is } \\
\text { practice }\end{array}$ & & & & & & $\mathrm{X}$ \\
\hline
\end{tabular}

In the closed questionnaire, for both groups of respondents, the rating very important was the most common (238 occurrences). In this regard, trainee-engineers and mentors gave an almost identical degree of importance to communication (selected by 20 trainees and by all six mentors) and teamwork, which placed third for 19 trainees and second for the six mentors.

Engineer-trainees and mentors share the classification of little importance for the concepts figurative language and mental models. The first did not appear during the course of the interviews. The second was defined and described in the interviews with the trainees and mentioned in the mentors' reports. A hypothesis is that the concept was evaluated as of little importance because it was not adequately explained in the enclosed questionnaire, giving room for ambiguity in interpretation. The concept trial and error is also of little importance to mentors. According to them, successive trials and errors may delay the progress, and time, of the project's product and is not beneficial to the Organization. Figures 7 and 8 show the results of the instrument's application.

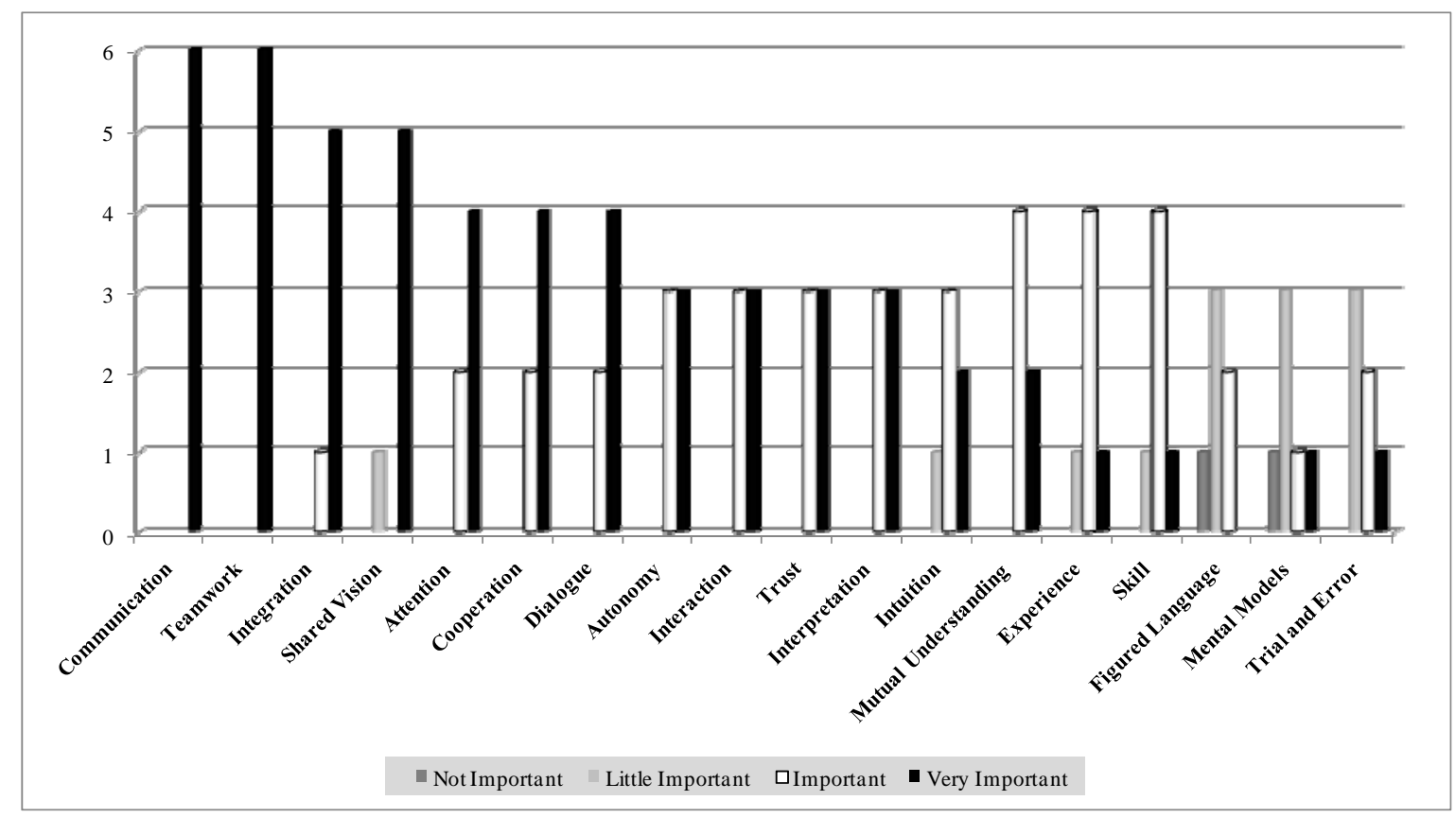

Figure 7. The Importance of Concepts of the Theoretical Reference Model for Engineer-Trainees. 


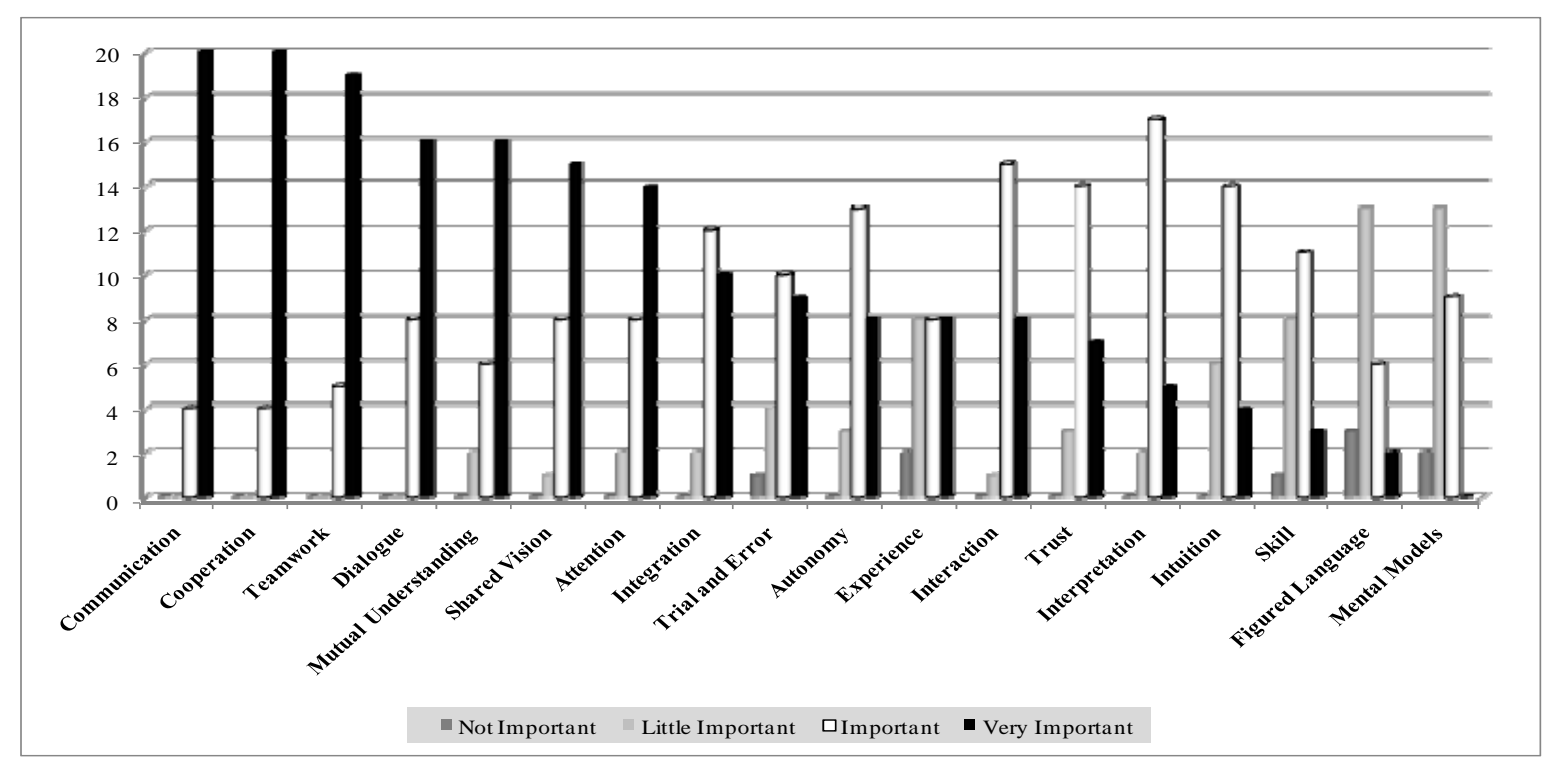

Figure 8. The Importance of Concepts of the Theoretical Reference Model for Mentors.

After comparative analysis of the Figures 7 and 8, an Empirical Representation (Figure 9) was obtained which aims to depict the interaction and mobilization of tacit knowledge between engineertrainees and mentors who are working in multidisciplinary teams in step 3 of ATPE of Challenge and resulting in learning (for individuals, team and the organization).

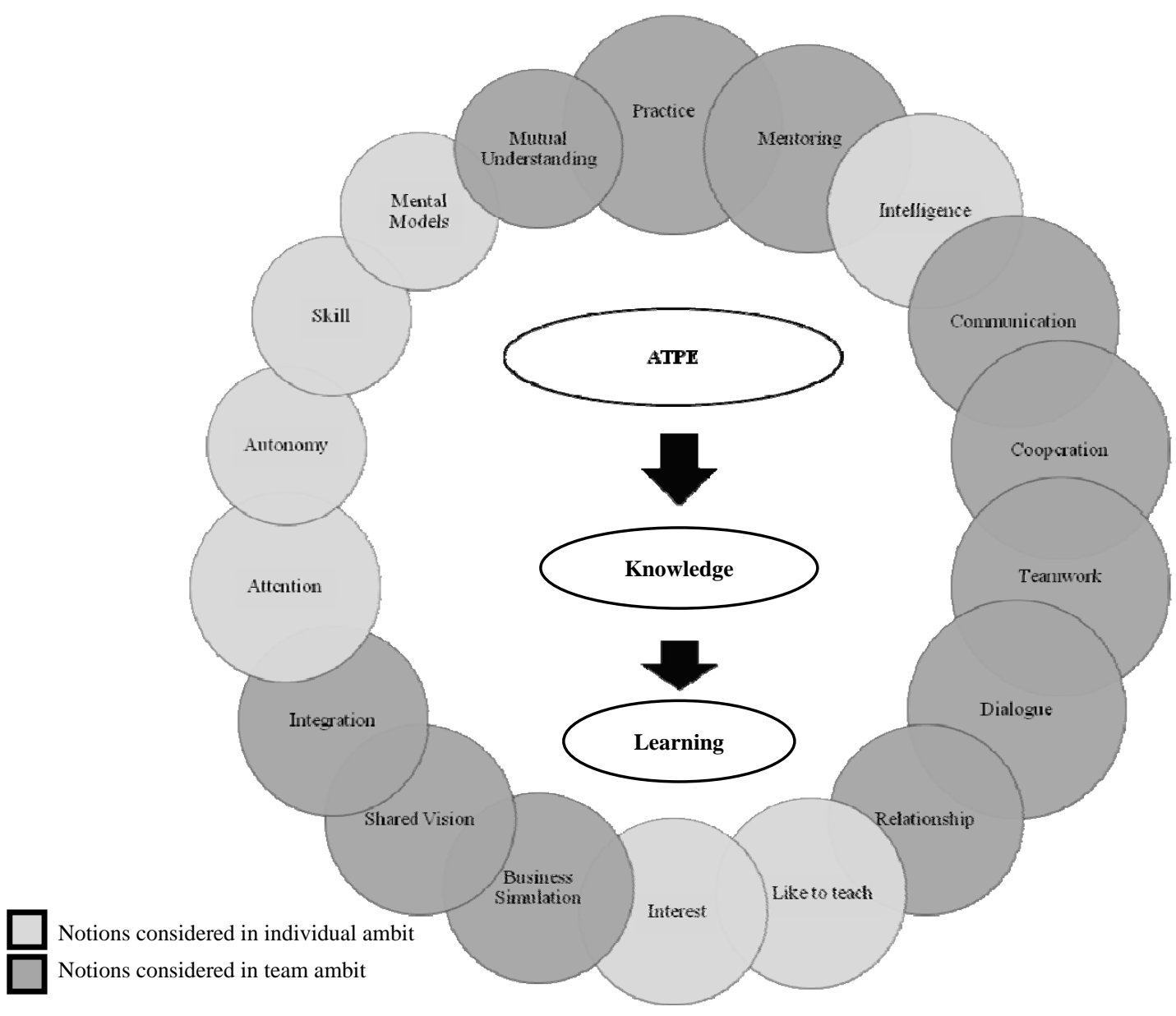

Figure 9. Empirical Representation of Team Learning in ATPE. 
In the center of Figure 9 is the ATPE and its direct relation with knowledge, resulting in learning for the participants. In all, 18 concepts comprise the Empirical Representation of Team Learning in the ATPE: seven considered at individual level, represented in pink, and 11 at the team level, highlighted in blue. Eleven concepts of the Theoretical Reference Model remain, with an additional seven new concepts. Three sizes of circles may be perceived in Figure 9. They represent different degrees of concepts' importance for the respondents.

The main criteria for the permanence of concepts from the Theoretical Reference Model in the Empirical Representation of Team Learning in the ATPE were: (a) finding that seven concepts were repeated in the testimonies of the respondents (during the implementation of the open questionnaire and individual interview) more frequently. They were: communication; cooperation; teamwork; dialogue; shared vision; integration and attention; (b) the concept autonomy was classified among the first 10 concepts as very important in the enclosed questionnaire by the two groups; (c) the concepts mental models, mutual understanding (conviviality of people from the same class, with mutual help) and ability (contact with company professionals, holders of know-how) were mentioned as facilitators of interaction and teaching/learning in ATPE. The concept mental models, even classified as of little importance, remains in Figure 9 for reasons already explained in this work.

It should be noted that the eight concepts with a greater number of classifications as very important by the trainees were chosen to appear in the new Model because they are also among the seven most important for the mentors (Figures 7 and 8). The exception is the concept mutual understanding, which remains in Figure 9 for the reason indicated in the preceding paragraph. The highlight of the first seven placements (Figure 8) is because until the seventh there was agreement of the majority of mentors in classifying the concept as very important. The seven new concepts in Figure 9 were chosen from two major findings: (a) they were emphasized and repeated during the first two stages of this research; and (b) they were considered to be facilitators of interaction and learning by both trainees and mentors.

Ending this topic, it can be affirmed that the perception and understanding of ATPE as and engine and proper driver for mobilization, exchange of knowledge and learning in multidisciplinary teams emerged repeatedly in the responses of mentors and engineer-trainees. This fact confirms testimonies given by the coordination of the Training Program, which labels knowledge and learning as the main objectives of the ATPE, permitting engineers from various specialties to enter Challenge's workforce. After analyzing the results, it was found that obtaining these objects in the Program occurs, mainly: through an intense load of theoretical content and information passed to engineertrainees in classes (steps 1 and 2 of ATPE); by contact with the members of class, that add proper intelligence and distinct world visions which complement team activities performed in stage 3 of the Program.

\section{Final Considerations}

Regarding the main goal of this study, it can be concluded that the mobilization of tacit knowledge and the interaction between engineer-trainees and mentors of ATPE results in learning. Because of that, the program is a viable initiative to break with the paradigms of expertise, an attitude that would make achievement of the complex work done by the Challenge difficult. Confirming this finding, the Empirical Representation of Team Learning in ATPE has 18 concepts, the same amount of the Theoretical Model of Reference, with the majority (11) coming from the authors that were used for reference in this research, which shows the significance in the choice of the experts and supports the main objective proposed here.

From the analysis of textual content of the interviews with the trainees, it was noted that 16 of the Reference Model concepts (out of 18) were defined/described in the context of ATPE, with the same (identical) meaning as the Reference Model, as shown in table 8. 'Interpretation' and 'figurative language' are missing. It's important to emphasize that the second was not even mentioned in the reports. 
Table 8

Definition of the Reference Model Given by Trainees

\section{THE REFERENCE MODEL CONCEPTS ACOORDING TO THE TRAINEES}

\section{Concept}

Attention

Autonomy

Communication

Trust

Cooperation

Dialogue

Mutual

Understanding

Experience

Ability

Interaction

Integration

Intuition

Mental models

Teamwork

\section{Definition/ description}

"Here in ATPE I tend to perform deep studies, including time off. I end up looking for much information about the things that I'm working with" (T7).

"He used that style of pointing out options, but not influencing the decision. I like it because I enjoy working with freedom "(T8).

"If a new idea appears, it’s argued, we view the pros and cons and we reach a consensus" (T11).

"You have to put faith that the person will do what he has to do, you have to trust" (T21).

"To cooperate is to do teamwork, helping each other, making the group work more profitably" (T11).

"You deal with different people and receive feedback. When being closer to people, sometimes people have more freedom to give you feedback. ... Then you have some help from the class and this 'opening' is interesting. We end up contributing to the growth of each other "(T2).

"Dealing with dissenting views is a part. If a new idea appears, it is argued, we see the pros and cons and we come to a consensus "(T11).

"Experience: to know the subject with which I'll work. It's different from the person who has entered the program now, without knowing anything "(T9).

"And the question of technique is what I think a sensible person, a person who has a little more intimacy with design, the technical part: counting, calculation, that sort of thing" (T1).

"Interaction is the constant exchange of ideas, both among people with the same emphasis as different emphases. Diversity of knowledge and ideas. Remember a little creativity. You sum it up and it has a diversity of ideas "(T13).

"It's a dependency issue. The area of each one depends on the output of other areas. I have to do my part and see how it influences the others "(T19).

"If I had to do it alone, it would take 50 times longer because I would have to identify interfaces one by one. As a team, it happened much faster. You have insights before "(T14).

"Each one follows a line of reasoning different from another, she has a world view different from another. So when you express a given problem, she will see with other eyes. Certain features will become apparent to this person that will not necessarily be the same for others. And any solution must be very clear to her, with the world knowledge that she has, and to others it may be not very clear "(T1).

"Learning is to try, make mistakes and resolve them in some way, even if it isn't the most correct, but somehow solve it in a manner that gives result" (T16).

"The teamwork was bigger because you have to negotiate. The team is putting together a puzzle and you are a part. You must respect the limitations and needs of other areas. It's not my way of making a product, but consider the whole, look at the global point of view. The good project is when no one is completely satisfied. Everyone has to 'give' a little bit. A complex product is complicated, advanced. You have to find middle ground between different areas and there is the benefit of working in teams, that's when you learn "(T14).

"Now (step 3), as people are divided and each person is working in an area, we have to learn for ourselves and then disseminate it to everybody. ... We have to learn and continue to know our area because the work is quite interdisciplinary; we are looked to transmit what we know "(T9). 
On several occasions in the testimonies of trainees, concepts of the Model were mentioned in the same statement, indicating interdependence. The quotes also seem to indicate the non-occurrence of stratification between them, showing that they're not understood as successive layers and/or overlapped, but as items which the simultaneously occurrence is relevant to learning in the context studied here. In the definition of communication, for example, there is also inherent aspects of dialogue, interaction and insights, concepts used by Nonaka and Takeuchi (1997); Crossan et al. (1999); Choo (2000, 2001); Choo and Johnston (2004); Garvin (2002); Senge (2006); Gorz (2005).

The results obtained in this research, lead to the understanding that the representation in Figure 9 can be used in Challenge's work environment as a guide to the present organizational behavior and to aspects that need to be improved. Because it is not something static and fixed, it may contribute to Knowledge Management in the company in that it forms a figure composed of interchangeable parts, in which the 18 concepts can be continuously changed; literally moved, swapped places from employees, indicating their occurrence (or absence) and the importance attached to them in each given situation and/or activity, signaling the possible need for change.

The discussion brought in this paper has at least two effective contributions to knowledge: the construction of a theoretical model of reference, based on a literature analysis that links different views on Organizational Learning, 'Organizations That Learn' and Knowledge Management, and after the analysis of research data, the construction of an Empirical Representation based on the Theoretical Model. Tests of the representation will allow the organization Challenge to consolidate (or disprove) the findings. This application will permit suggestions for changes in the Theoretical Model used.

As suggestions of continuity, other studies may address the following perspectives: (a) validation of the Empirical Representation of Team Learning in ATPE with participants and exparticipants of the Program; (b) converse with ex-students and administrators of ATPE, to find out if (and how) the participation in the Program contributed to any activities currently existing in Challenge; (c) interview employees of Challenge that did not participate in the ATPE in order to understand their perceptions about mobilization of knowledge and teamwork; (d) further investigate the perception of engineer-trainees and mentors about the concept mental models in relation to daily work activities; (e) study the extent of explicit or technical knowledge, such as its importance, uses and contributions when it's socialized in teamwork; (f) identify other concepts that are relevant to learning at the group level in other professional sectors, for other purposes or organizational contexts.

\section{Received 14 October 2009; received in revised form 15 October 2010.}

\section{Acknowledgements}

Foundation for Support of Science and Technology of the Espírito Santo (FAPES) for the support which enabled the development of this research.

\section{References}

Badaracco, J. L. (1991). The knowledge link: how firms compete through strategic alliances. Boston, MA: Harvard Business School Press.

Brannen, J. (2004). Working qualitatively and quantitatively. In C. Seale, G. Gobo, J. F. Gubrium, D. Silverman (Orgs.), Qualitative research practice (pp. 312-326). London: SAGE Publications Ltd. 
Castañeda, D. I., \& Pérez-Acosta, A. (2005). Como se produce el aprendizaje individual em el aprendizaje organizacional? Una explicación más allá del proceso de intuir. Revista Interamericana de Psicologia Ocupacional, 24(1-2), 1-15. Retrieved from http://aprendizajeorganizacional.freeservers.com/aprendindorg.htm

Castañeda, D. I., \& Ríos, M. F. (2007). From individual learning to organizational learning. The Electronic Journal of Knowledge Management, 5(4), 363-372. Retrieved from http://www.ejkm.com/issue/download.html?idArticle=120

Choo, C. W. (2000). Working with knowledge: how information professionals help organizations manage what they know. Library Management, 21(8), 395-403. doi: $10.1108 / 01435120010342770$

Choo, C. W. (2001). The knowing organization as learning organization. Education + Training, 43(45), 197-205. doi: 10.1108/EUM0000000005482

Choo, C. W., \& Johnston, R. (2004). Innovation in the knowing organization: a case study of an ecommerce initiative. Journal of Knowledge Management, 8(6), 77-92. doi: $10.1108 / 13673270410567648$

Crossan, M. M., Lane, H. W., \& White, R. E. (1999). An organizational learning framework: from intuition to institution. Academy of Management Review, 24(3), 522-537. doi: 10.2307/259140

Davidz, H. L., Nightingale, D. J., \& Rhodes, D. H. (2005, March). Enablers and barriers to systems thinking development: results of a qualitative and quantitative study. Proceedings of the Conference on Systems Engineering Research, Hoboken, NJ, USA. Retrieved from http://sse.stevens.edu/fileadmin/cser/2005/papers/35.pdf

Garvin, D. (2002). Aprendizagem em ação: um guia para transformar sua empresa em uma learning organization. Rio de Janeiro: Qualitymark.

Gil, A. C. (1999). Métodos e técnicas de pesquisa social. São Paulo: Atlas.

Gorz, A. (2004). Misérias do presente, riqueza do possível. São Paulo: Annablume.

Gorz, A. (2005). O imaterial: conhecimento, valor e capital. São Paulo: Annablume.

Harvey, D. (2007). Condição pós-moderna: uma pesquisa sobre as origens da mudança cultural. São Paulo: Loyola.

Kiedrowski, P. J. (2006). Quantitative assessment of a Senge learning organization intervention. Emerald Group Publishing Limited, 13(4), 369-383. doi: 10.1108/09696470610667742

Kvale, S. (2006). Dominance through interviews and dialogues. Qualitative Inquiry, 12(3), 480-500. doi: $10.1177 / 1077800406286235$

Li, M., \& Gao, F. (2003). Why Nonaka highlights tacit knowleged: a critical review. Journal of Knowleged Management, 7(4), 6-14. doi: 10.1108/13673270310492903

Nonaka, I., \& Takeuchi, H. (1997). Criação de conhecimento na empresa: como as empresas japonesas geram a dinâmica da inovação. Rio de Janeiro: Elsevier.

Pimenta, S. G., \& Anastasiou, L. G. C. (2002). Docência no ensino superior. São Paulo: Cortez.

Roesch, S. M. A. (1999). Projetos de estágio e de pesquisa em administração: guias para estágios, trabalhos de conclusão, dissertações e estudo de casos. São Paulo: Atlas. 
Rozenfeld, H., Forcellini, F. A., Amaral, D. C., Toledo, J. C., Silva, S. L., \& Allprandini, D. H. (2006). Gestão de desenvolvimento de produtos: uma referência para a melhoria do processo. São Paulo: Saraiva.

Rullani, E. (2000a). Le capitalisme cognitif: du déjà vu? Multitudes, (2), 87-94. Retrieved from http://multitudes.samizdat.net/Le-capitalisme-cognitif-du-deja-vu. doi: 10.3917/mult.002.0087

Rullani, E. (2000b). Producción de conocimiento y valor en el postfordismo. Multitudes, (2), 1-5. Retrieved from http://multitudes.samizdat.net/Produccion-de-conocimiento-y-valor.

Ryan, G. W., \& Bernard, H. R. (2000). Data management and analysis methods. In N. K. Denzin \& Y. S. Lincoln (Eds.), Handbook of Qualitative Research (pp. 428-444). London: Sage Publications.

Salerno, M. S. (1999). Projeto de organizações integradas e flexíveis: processos, grupos e gestão democrática via espaços de comunicação-negociação. São Paulo: Atlas.

Schwartz, Y. (1994). Trabalho e gestão: níveis, critérios, instâncias. In M. Figueiredo, M. Athayde, J. Brito, \& D. Alvarez (Orgs.), Labirintos do trabalho: interrogações e olhares sobre o trabalho vivo (pp. 1-12). Rio de Janeiro: DP\&A.

Schwartz, Y. (2003, maio). Trabalho e saber. Seminário internacional trabalho e saber. Belo Horizonte.

Senge, P. M. (2006). A quinta disciplina: arte e prática da organização que aprende. Rio de Janeiro: Best Seller.

Toffler, A. (1994). O choque do futuro. Rio de Janeiro: Record.

Veltz, P., \& Zarifian, P. (1993). Vers de nouveaux modeles d'organisation? Sociologie du Travail, 35(1), 3-25.

Zietsma, C., Winn, M., Branzei, O., \& Vertinsky, I. (2002). The war of the woods: facilitators and impediments of organizational learning processes. British Journal of Management, 13(S2), S61S74. doi: 10.1111/1467-8551.13.s2.6 